\title{
Marlena Duda
}

https://orcid.org/0000-0001-9168-808X

Uniwersytet Marii Curie-Skłodowskiej

\section{Satysfakcja z życia a zasoby podmiotowe u osób bezrobotnych}

\author{
Life satisfaction and subjective resources in the situation \\ of unemployment
}

\begin{abstract}
Streszczenie. Bezrobocie to obecnie jeden z najistotniejszych problemów o charakterze społecznym i indywidualnym, wymagającym, ze względu na swoją charakterystykę, zasięg i skutki, pogłębionego i krytycznego podejścia do rozumienia złożonych zagadnień funkcjonowania człowieka w tej wyjątkowej sytuacji. W artykule przedstawiono wyniki badań własnych poświęconych analizie predykcyjnych funkcji zasobów podmiotowych w kształtowaniu satysfakcji z życia osób bezrobotnych. Wykazano istotne dodatnie powiązania satysfakcji z życia z optymizmem dyspozycyjnym i poczuciem własnej skuteczności oraz ujemne z inteligencją emocjonalną. Wyniki te potwierdzają wcześniejsze doniesienia z literatury dotyczące wkładu optymizmu i samoskuteczności w kształtowanie zadowolenia z życia. Natomiast ubogi stan badań dotyczący inteligencji emocjonalnej osób bezrobotnych wskazuje na potrzebę eksploracji tego zagadnienia.
\end{abstract}

Słowa kluczowe: bezrobocie; zasoby podmiotowe; satysfakcja z życia

Summary. Unemployment is currently one of the most important social and individual problems requiring (given its characteristics, scope, and effects) a deeper and more critical approach to understanding the complex issues of a person functioning in this unique situation. The article presents the results of own research dedicated to the analysis of predictive functions of subjective resources in shaping the life satisfaction of the unemployed. Significant positive associations when it comes to the life satisfaction, availability optimism, and the sense of self-efficacy, as well as negative associations regarding emotional intelligence were shown. These results confirm earlier reports from the literature on the contribution of optimism and self-efficacy in the shaping of life satisfaction. On the other hand, the poor state of research concerning the emotional intelligence of the unemployed indicates the need to explore this issue.

Keywords: unemployment; subjective resources; life satisfaction 


\section{Wprowadzenie}

Powszechność zjawiska bezrobocia oraz jego skutki czynią z niego naglący problem o charakterze indywidulanym i społecznym. Stopa bezrobocia rejestrowanego w Polsce w 2019 roku (stan na koniec września 2019 roku) wyniosła 5,1\% (stat.gov.pl), a dane te nie obejmują osób, które z różnych przyczyn nie rejestrują się $\mathrm{w}$ urzędach pracy bądź są osobami biernymi zawodowo. Sytuacja ta nie wynika bezpośrednio z indywidualnych decyzji osób bezrobotnych, a jest ona warunkowana przez szereg czynników tkwiących w charakterze nieustannie zmieniających się okoliczności związanych $\mathrm{z}$ rynkiem pracy. Zachodzące zmiany $\mathrm{w}$ zatrudnieniu powodują większe trudności w utrzymaniu stanowiska pracy niż w jego zdobyciu. Elastyczne formy zatrudnienia, charakter zadaniowy pracy, mnogość ofert pracy poniżej kwalifikacji i niewielkie wynagrodzenia za wykonywaną pracę przyczynia się do utrzymywania zjawiska bezrobocia. Brak stabilizacji zawodowej i ochrony przed zwolnieniem, nieustanne dopasowywanie się do zmieniających się okoliczności, niekorzystna zmiana relacji czasu wolnego do czasu pracy i niestabilna natura rynku pracy pogłębia analizowany problem (Myszka-Strychalska 2018; Wojciechowska 2018; Duda 2019). Poważne problemy z zatrudnieniem obecnie dotyczą zarówno osób młodych, dopiero odnajdujących się na rynku pracy, jak i osób w średnim wieku, z wykształceniem wyższym i średnim (Wojciechowska 2018). Natężenie bezrobocia jest również silnie zróżnicowane regionalnie. W drugim kwartale 2019 roku najniższą stopę bezrobocia odnotowano w województwie śląskim $(1,8 \%)$ i lubuskim (2,1\%), natomiast najwyższą w województwie lubelskim (5,5\%), podkarpackim $(5,2 \%)$ i świętokrzyskim $(5,0 \%)$ (stat.gov.pl). Sytuacja ta generuje nowe potrzeby w zakresie przezwyciężania tego zjawiska i w większym stopniu akcentuje umiejętności szybkiej adaptacji do nagle zmieniających się warunków.

Badania nad zjawiskiem bezrobocia najczęściej prowadzone są w trzech obszarach: wpływu na zdrowie fizyczne i psychiczne, procesu poszukiwania pracy oraz efektywności interwencji i pomocy z dwóch perspektyw: makro (ekonomia) i mikro (podkreślające indywidualne doświadczenia osób bezrobotnych) (Wanberg 2010).

Sytuacja utraty pracy jest krytycznym wydarzeniem życiowym generującym wysoki poziom stresu (Park i in. 2009), wpływającym na całokształt funkcjonowania człowieka poprzez wywoływanie szeregu negatywnych skutków (McKee-Ryan i in. 2005; Brand 2015), najczęściej w postaci obniżenia stanu zdrowia fizycznego i psychicznego (Paul, Moser 2009; But- 
terworth i in. 2012; Ishmuhametov, Palma 2017), prowadzącym do depresji (Mossakowski 2009; Wang i in. 2014, s. 61), wzmożonego poczucia lęku (Caspi i in. 1998; Kokko i in. 2000) i samobójstw (Kposowa 200; Blakely 2003; Andrés 2005; Classen, Dunn 2012), przy czym „korelacyjny charakter większości badań nad bezrobociem nie przesądza o kierunku zależności między badanymi zmiennymi, stąd często nie wiadomo, na ile określony stan psychiczny bezrobotnego jest konsekwencją, a na ile przyczyną braku pracy. Relacja ta może mieć także charakter złożony" (Derbis 2000, s. 10). Co więcej, istnieją dowody potwierdzające okaleczający wpływ zjawiska bezrobocia na przyszłość zawodową osoby, nawet w obliczu poprawy sytuacji finansowej i nowego zatrudnienia (Clark i in. 2001; Mousteri i in. 2018). Przedłużająca się bierność zawodowa sprzyja również nadużywaniu alkoholu i nikotyny (Kulik i in. 2008), utracie kontaktów społecznych i rodzinnych (Kalil 2009; Lubińska-Bogacka 2011), stanowi czynnik ryzyka chorób układu krążenia (Janicki-Deverts i in. 2008), prowadząc do obniżenia standardu życia, a w konsekwencji również obniżenia jakości życia (Kirenko, Duda 2018). Warto jednak podkreślić, że „mimo potencjalnie podobnego wpływu utraty pracy, sytuacji bezrobocia i skutków długotrwałych poszukiwań zatrudnienia bez pozytywnego skutku, osoby bezrobotne są tak samo różne, jak osoby pracujące, różne jest bowiem ich wyposażenie psychologiczne oraz różne są sytuacje społeczne, w których żyją. Stąd zarysowane spektrum problemów występuje w bardzo różnym natężeniu i konfiguracjach w przypadku różnych osób" (Kalbarczyk 2011, s. 105; van Hoye, Lootens 2013).

Satysfakcja z życia to subiektywna ocena całokształtu sytuacji życiowej, bezpośrednio odnosząca się do „indywidualnego wartościowania posiadanych zasobów i ograniczeń, znajdując[a] wyraz w pozytywnym ustosunkowaniu się do własnej sytuacji życiowej i przejawianiu uczuciowych reakcji przyjemności w związku z pełnionymi rolami życiowymi" (Juczyński 2001). Jest to ocena względnie trwała (aspekt poznawczy subiektywnego dobrostanu) i kształtuje się w dłuższej perspektywie czasowej, m.in. pod wpływem wydarzeń życiowych (Pavot, Diener, 1993, za: Juczyński 2001). Co więcej, owa ostateczna ocena jest wynikiem konfrontacji obecnej sytuacji z ustalonymi przez siebie standardami i koreluje z realizacją celów i zaspokajaniem ważnych, z punktu widzenia osoby, potrzeb. Satysfakcja z życia czy subiektywny dobrostan pełnią ważną funkcję regulacyjną w kształtowaniu samopoczucia psychicznego osób bezrobotnych, przyczyniając się do łagodzenia skutków stresu wywołanego utratą pracy i szybszego znajdowania nowego zatrudnienia (van Hoye, Lootens 2013; Peláez-Fernández i in. 2019). 
Zbadanie indywidualnych determinantów pozytywnego funkcjonowania osób bezrobotnych i ich udziału w kształtowaniu satysfakcji z życia jest zarówno interesujące poznawczo, jak i przydatne z punktu widzenia strategii pomocy osobom bezrobotnym w owocnym powrocie na rynek pracy.

\section{Bezrobocie a zasoby}

W ponownym zatrudnieniu osób bezrobotnych istotną rolę odgrywają czynniki związane zarówno z sytuacją na rynku pracy, jak i z indywidualnymi cechami osób bezrobotnych. Do tych, które mają udokumentowany wpływ na efektywność uzyskania ponownego zatrudnienia, zalicza się zapotrzebowanie rynku pracy na pracowników (i w skali kraju, i regionu), intensywność poszukiwania pracy, wiedza, umiejętności i doświadczenie osoby bezrobotnej oraz wsparcie społeczne (Wanberg $i$ in. 2002). Rozszerzeniem tego modelu są badania nad indywidualnymi czynnikami efektywnego zatrudnienia, które wliczają również umiejętność dostosowania się do nowych sytuacji, optymizm, samoskuteczność, inteligencję emocjonalną, elastyczność oraz szereg warunków socjodemograficznych (Fugate i in. 2004). Znaczące są zatem te czynniki, które mają ogromne znaczenie $\mathrm{w}$ radzeniu sobie ze stresem, zwane zasobami. Do zasobów należą „przedmioty, warunki, cechy osobowości i pokłady energii, które albo są cenione same w sobie jako potrzebne do przetrwania (bezpośrednio lub pośrednio), albo służą do zdobycia owych zasobów umożliwiających przetrwanie" (Hobfoll 2006, s. 61). Frances McKee-Ryan i wsp. (2005) zidentyfikowali cztery rodzaje zasobów potrzebnych do radzenia sobie z sytuacją braku pracy. Są to zasoby podmiotowe (osobiste), społeczne i finansowe, które odgrywają szczególną rolę w radzeniu sobie $\mathrm{z}$ negatywnymi skutkami bezrobocia, oraz temporalne (struktura czasowa). Wszystkie grupy identyfikowane są jako istotne dla dobrego samopoczucia w okresie bezrobocia, a satysfakcja z życia w tym okresie jest ważnym predyktorem efektywnego poszukiwania pracy.

Zgodnie z powyższymi rezultatami empirycznymi na ocenę sytuacji i zachowań związanych $z$ radzeniem sobie $z$ bezrobociem mają wpływ zasoby podmiotowe charakteryzowane jako „względnie trwale, dyspozycyjne, poznawczo-afektywne i behawioralno-kompetencyjne wyposażenie człowieka, spełniające swoje ochronne i moderujące stres funkcje poprzez ingerencję w przebieg procesów oceny poznawczej i radzenia sobie, których rezultaty mogą zwrotnie wpływać, a nawet zmieniać psychologiczne zasoby człowieka" (Wrona-Polańska 2012, s. 18). W prezentowanych badaniach wy- 
brano zasoby zgodnie z modelem Mel Fugate: samoskuteczność, optymizm $i$ inteligencja emocjonalna (Fugate i in. 2004).

Poczucie własnej skuteczności jest istotnym zasobem w radzeniu sobie z sytuacją trudną (Han 2005) i rozumiane jest jako przekonanie osoby co do umiejętności realizacji celów bez względu na otaczające stresujące warunki (Juczyński 2001). Osoby, które uzyskały lepsze wyniki w zakresie własnej skuteczności, mają mniejsze szanse na wystąpienie objawów depresji (Tahmassian, Moghadam 2011). Ponadto samoskuteczność odgrywa istotną rolę w łagodzeniu jej objawów (Wang i in. 2014). Badania wskazują, że osoby z wyższym poziomem samoskuteczności są w mniejszym stopniu zagrożone ryzykiem utraty pracy (Pinquart i in. 2003), a gdy dojdzie do takiej sytuacji, szybciej znajdują zatrudnienie i lepiej radzą sobie z wyzwaniami w nowym miejscu pracy (Ślebarska, Chudzicka-Czupała 2013). W przypadku badań osób bezrobotnych samoskuteczność stanowi ważny predyktor w poszukiwaniu pracy oraz gotowości do podjęcia szkoleń (Creed i in. 2001). Wyniki potwierdzają istotną korelację niższego poczucia własnej skuteczności z długością czasu pozostawania poza rynkiem pracy (Liu i in. 2014) i niższą motywacją do jej podjęcia, nawet $\mathrm{z}$ ryzykiem całkowitego zaprzestania poszukiwań zatrudnienia (Brown i in. 2006). Jest również mediatorem związku cech osobowości i objawów depresji wśród osób bezrobotnych (Wang i in. 2014, s. 66). Do cech wspierających radzenie sobie z sytuacją zarówno bycia zatrudnionym, jak i bezrobotnym, oprócz poczucia własnej skuteczności, zalicza się dyspozycyjny optymizm i inteligencję emocjonalną.

Optymizm jest cechą wyrażającą się pozytywnym nastawieniem wobec zdarzeń w przyszłości, sprzyja odnoszeniu sukcesów i radzeniu sobie ze stresem. Badania potwierdzają związek optymistycznego nastawienia z sytuacją zawodową, wykazując, że osoby optymistyczne charakteryzują się wyższymi wskaźnikami satysfakcji zawodowej (Munyon i in. 2010), mają niższe poczucie niepewności zatrudnienia (Li i in. 2019), a w przypadku utraty pracy lepiej radzą sobie z sytuacją bezrobocia i potrafią łagodzić jego skutki (Lai, Wong 1998; Lee 2008). „Zasób osobisty w postaci optymizmu dyspozycyjnego zmniejsza ryzyko załamania psychologicznego, depresji bądź zdominowania ostatniego okresu życia przez negatywne emocje, odczucia straty, ubytków czy zgeneralizowane poczucie krzywdy" (Liberska 2016, s. 229). Jest umiarkowanym mediatorem zależności między wsparciem społecznym a poszukiwaniem pracy u osób bezrobotnych (Ślebarska i in. 2009).

Świadomość stanów emocjonalnych jest istotną zdolnością do rozumienia swoich i cudzych emocji oraz wykorzystywania zdobytych na tej drodze informacji do efektywnego działania (Mayer, Salovey 1999). Inteligen- 
cja emocjonalna to „zdolność do rozumienia własnych i cudzych uczuć oraz do wykorzystywania emocji w myśleniu i działaniu" (Śmieja, Orzechowski 2008, s. 20). Wysoki poziom inteligencji emocjonalnej jest przydatny w pracy zawodowej (Druskat, Wolff 2001; Wong, Law 2002; Matsumoto i in. 2004; por. Jordan i in. 2002) choć nie ma dotychczas wyników badań jednoznacznie potwierdzających, że determinuje ona sukces zawodowy w większym stopniu niż typ osobowości czy inteligencja ogólna (Derksen i in. 2002; Zeidner i in. 2004). Jest natomiast potwierdzona pozytywna rola tego zasobu w radzeniu sobie $z$ sytuacją bezrobocia i utrzymywaniu dobrostanu (Hodzic i in. 2015; Berriors i in. 2016; Peláez-Fernández i in. 2019).

\section{Metodologiczne założenia badań własnych}

Przegląd dotychczasowej literatury potwierdził empiryczne dowody na związek między zasobami podmiotowymi i subiektywnym dobrostanem. Dążenie do ustanowienia i utrzymania poczucia kontroli nad własnym życiem i otoczeniem, optymizm, rozumienie emocji mogą służyć modyfikacji oceny stresu i w efekcie pozytywnie neutralizować jego oddziaływanie, co znacząco może przyczynić się do podniesienia efektywności poszukiwania i utrzymania miejsca pracy, dlatego celem podjętych analiz jest charakterystyka powiązań satysfakcji z życia osób bezrobotnych z wybranymi zasobami podmiotowymi.

Przyjęto, że zasoby podmiotowe, jak: dyspozycyjny optymizm, samoskuteczność i inteligencja emocjonalna, są ważnymi predyktorami wysokiej satysfakcji z życia, co sprzyja efektywnemu radzeniu sobie z sytuacją bezrobocia i przyczyniają się do skutecznego poszukiwania pracy. W tak prezentowanym modelu badań postawiono następujące problemy badawcze:

1. Jaki jest poziom poczucia skuteczności, dyspozycyjnego optymizmu, inteligencji emocjonalnej oraz satysfakcji z życia osób bezrobotnych?

2. Czy istnieje, a jeśli tak, to jaka jest zależność pomiędzy satysfakcją z życia osób bezrobotnych a zasobami podmiotowymi, takimi jak: własna skuteczność, inteligencja emocjonalna oraz optymizm osób bezrobotnych?

3. Czy i w jakim stopniu takie zasoby podmiotowe jak: własna skuteczność, inteligencja emocjonalna oraz optymizm uczestniczą w wyjaśnianiu zmienności satysfakcji z życia u osób bezrobotnych?

Dane empiryczne zebrano za pomocą metody sondażu diagnostycznego, techniki ankiety oraz kwestionariusza ankiety, w skład którego wchodziły następujące narzędzia badawcze: Skala Uogólnionej Własnej Skutecz- 
ności (GSES) Ralfa Schwarzera i Michaela Jerusalem w adaptacji Zygfryda Juczyńskiego (2001), Test Orientacji Życiowej (LOT-R) Michaela Scheiera i Charlesa Carvera w adaptacji Ryszarda Poprawy i Zygfryda Juczyńskiego (2001), Skala Satysfakcji z Życia (SWLS) Eda Dienera i wsp. (1985) w adaptacji Zygfryda Juczyńskiego (2001), Skala Inteligencji Emocjonalnej Nicoli S. Schutte i wsp. (1998) w adaptacji Anny Matczak, Aleksandry Jaworowskiej (2008) oraz metryczka. Wykorzystane w badaniach narzędzia bazujące na koncepcji samoopisu wykazują pewne ograniczenia, badania miały również charakter przekrojowy i zostały przeprowadzone na niewielkiej grupie osób bezrobotnych, a więc jego wyniki należy ostrożnie uogólniać na populację.

Badaniami objęto 96 słuchaczy kursów przygotowujących do powrotu na rynek pracy. Były to osoby zarejestrowane w powiatowym urzędzie pracy przez okres dłuższy niż 12 miesięcy, co klasyfikowało je jako osoby długotrwale bezrobotne (stat.gov.pl). Badania miały charakter anonimowy, a zaproszone osoby zostały poinformowane o dobrowolności udziału w badaniach. Najliczniejszą grupę (ponad 60\%) stanowiły osoby młode powyżej 24 lat. Wykazano przy tym istotną zależność między wiekiem a problemami w uzyskaniu zatrudnienia $\left(\mathrm{chi}^{2}=19,529, \mathrm{df}=9, \mathrm{p}=0,021\right)$. Wśród badanych zdecydowanie przeważały kobiety (65\%). Statystycznie to również one częściej nie posiadały stałego źródła zatrudnienia $\left(\mathrm{chi}^{2}=15,771, \mathrm{df}=3, \mathrm{p}=0,001\right)$. Większość badanych mieszkała w mieście (56 osób). Poziom wykształcenia badanych osób był w miarę jednakowo rozłożony z niewielką przewagą osób z wykształceniem średnim (37,6\%). Wykazano korelację między wykształceniem a sytuacją bezrobocia $\left(\mathrm{chi}^{2}=19,947, \mathrm{df}=18, \mathrm{p}=0,000\right)$. Ponad $82 \%$ nie stwierdza u siebie żadnych problemów zdrowotnych, w badanej grupie nie było również osób z niepełnosprawnością.

Otrzymane wyniki poddane zostały analizie statystycznej pod kątem zależności między badanymi zmiennymi oraz w celu ustalenia predyktorów wysokiej satysfakcji z życia. Zmiennymi wyjaśniającymi były posiadane zasoby: poczucie samoskuteczności, optymizm, inteligencja emocjonalna. Zakłada się, że istnieje współzależnościowy charakter związku między analizowanymi zmiennymi.

\section{Analiza wyników badań własnych}

W pierwszym etapie analiz dokonano charakterystyki badanej grupy pod kątem nasilenia badanych zjawisk (rys. 1) oraz przeprowadzono analizę korelacyjną (tabela 1). Przeliczone na steny wyniki surowe badanych zmiennych 
pozwalają na wstępną charakterystykę grupy. Bezrobotni w przeważającej części (42,7\%) wykazują niski poziom satysfakcji z życia i dyspozycyjnego optymizmu (42,7\%). Zauważalnie najwięcej osób badanych uzyskało wyniki niskie, zwłaszcza w obrębie inteligencji emocjonalnej (95,8\%). Warto zwrócić uwagę na fakt, że jednocześnie znaczna ich liczba cechuje się wysokim natężeniem poczucia samoskuteczności (46,9\%), co wskazuje na świadomość posiadanej wiary w swoją skuteczność w realizacji zadań i celów osób bezrobotnych, bez względu na towarzyszące okoliczności. Tym samym w przypadku satysfakcji z życia osoby te charakteryzowały się wynikiem przeciętnym i niskim, co świadczy, że negatywnie ustosunkowują się do swojego życia jako całości, oceniają je nisko, wskazując na niezaspokojone potrzeby, utratę lub trudności w uzyskaniu ważnych z własnej perspektywy dóbr materialnych i niematerialnych. Osoby bezrobotne, porównując swoją obecną sytuację, determinowaną brakiem zatrudnienia, do swoich standardów życiowych, doświadczają wewnętrznej deprywacji potrzeb. Zatem widoczna w badaniach niska satysfakcja z życia jest najprawdopodobniej wynikiem długotrwałego oddziaływania sytuacji bezrobocia. Zaskakujący jest wynik wskazujący, że niemalże wszyscy badani bezrobotni charakteryzują się niskimi wynikami w obrębie inteligencji emocjonalnej, co wskazuje na ich trudności w rozumieniu własnych emocji i innych osób oraz wykorzystywaniu ich w działaniu i osiąganiu celów.

\section{Rysunek 1. Rozkład wyników badanych zmiennych w przeliczeniu na skale stenowe}

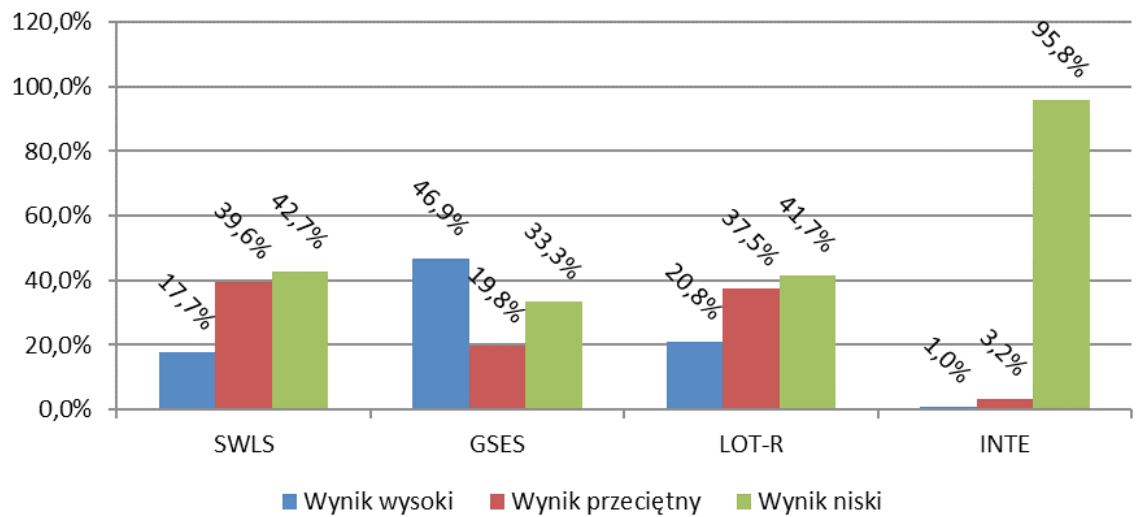

Źródło: opracowanie własne. 
Analiza korelacyjna wykazała, że istnieją istotne statystyczne zależności między badanymi zmiennymi. Satysfakcja z życia istotnie wiąże się z poczuciem samoskuteczności, dyspozycyjnym optymizmem i inteligencją emocjonalną (tabela 1).

\section{Tabela 1. Związek między satysfakcją z życia a zasobami osobistymi osób bezrobotnych}

\begin{tabular}{|c|c|c|c|c|c|c|}
\hline \multirow{2}{*}{ Zmienna } & \multicolumn{5}{|c|}{ Korelacja między satysfakcją z życia a zasobami podmiotowymi badanych osób } \\
\cline { 2 - 7 } & poczucie samoskuteczności & \multicolumn{2}{c|}{ optymizm dyspozycyjny } & \multicolumn{2}{|c|}{ inteligencja emocjonalna } \\
\cline { 2 - 7 } & $p$ & $r$ & $p$ & $r$ & $p$ & $r$ \\
\hline $\begin{array}{c}\text { Satysfakcja } \\
\text { z życia }\end{array}$ & 0,000 & 0,421 & 0,000 & 0,276 & 0,000 & $-0,324$ \\
\hline
\end{tabular}

Źródło: opracowanie własne, $p<0,05$.

Uzyskane współczynniki korelacji pokazują pozytywne związki między satysfakcją z życia a przekonaniami na temat własnego funkcjonowania i realizacji celów (samoskuteczność) oraz proaktywną postawę wobec działań i planów (optymizm dyspozycyjny) przy negatywnym związku satysfakcji z życia i zdolności do rozumienia emocji własnych i innych ludzi. Uzyskane wyniki pozwoliły na zastosowanie analizy regresji, dlatego w kolejnym kroku przeanalizowano udział zasobów podmiotowych w wyjaśnianiu natężenia satysfakcji z życia osób bezrobotnych (tabela 2).

\section{Tabela 2. Wyniki regresji krokowej - zmienna zależna satysfakcja z życia osób bezrobotnych}

\begin{tabular}{|c|c|c|c|c|}
\hline \multirow{3}{*}{ Wskaźnik zmiennych niezależnych } & \multicolumn{4}{|c|}{ Satysfakcja z życia } \\
& \multicolumn{4}{|c|}{$F(1,95)=13,805$} \\
\cline { 2 - 5 } & $\beta$ & $B$ & $t$ & $p$ \\
\hline Poczucie samoskuteczności & 0,358 & 0,382 & 3,72 & $0,000^{*}$ \\
\hline Optymizm dyspozycyjny & 0,261 & 0,305 & 2,62 & $0,010^{*}$ \\
\hline Inteligencja emocjonalna & $-0,357$ & $-0,118$ & $-3,71$ & $0,000^{*}$ \\
\hline
\end{tabular}


Poczucie satysfakcji z życia osób bezrobotnych można wyjaśnić przy udziale poczucia samoskuteczności, optymizmu dyspozycyjnego oraz inteligencji emocjonalnej. Zatem wyższy poziom zadowolenia z życia zależny jest od wyższej wiary w swoje zdolności do organizowania i realizacji działań oraz bardziej optymistycznego nastawienia wobec życia. W badanej grupie wskazano istotny i dodatni związek między silniejszymi przekonaniami o osobistym wpływie na skuteczność w realizacji zamierzonych celów i wiarą w ich powodzenie. W przypadku zdolności do rozumienia emocji wykazano istotny ujemny związek z poznawczą oceną własnego życia. Większa satysfakcja życiowa podlega wyjaśnieniu przez obniżone zdolności do wewnętrznego analizowania emocji i rozumienia emocji innych, a tym samym niższe możliwości wykorzystywania tej wiedzy w pracy zawodowej i życiu codziennym. W przypadku osób bardzo wrażliwych o wysokiej inteligencji emocjonalnej może dochodzić do zaniżenia satysfakcji z życia w wyniku wysokiego dysonansu między obecnymi a oczekiwanymi standardami życia. To zestawienie zmiennych pozwala wyjaśnić około $36 \%$ wariancji poczucia satysfakcji z życia badanych osób bezrobotnych.

\section{Zakończenie}

Wśród czynników warunkujących przebieg radzenia sobie z sytuacją bezrobocia wymienia się zasoby osobiste. Mają one znaczenie w łagodzeniu stresu związanego $\mathrm{z}$ utratą pracy i trwającym bezrobociem oraz przyczyniają się do efektywnych działań związanych z powrotem na rynek pracy. Prezentowane badania zostały zaprojektowane w celu ustalenia udziału zasobów podmiotowych w kształtowaniu satysfakcji z życia osób bezrobotnych. Dotychczasowe wyniki wskazywały, że takie zasoby jak samoskuteczność, optymizm czy inteligencja emocjonalna są istotnymi predyktorami satysfakcji z życia i pozytywnego dobrostanu (McKee-Ryan i in. 2005; Moore i in. 2017), natomiast dotychczas niewiele było doniesień o czynnikach kształtujących tę zmienną w sytuacji braku pracy.

Podjęte badania skoncentrowane były na ocenie satysfakcji z życia w odniesieniu do zasobów podmiotowych: poczucia samoskuteczności, dyspozycyjnego optymizmu i inteligencji emocjonalnej. Fakt niskiej satysfakcji z życia osób bezrobotnych nie budzi zdziwienia, wpisuje się również w dotychczasowe badania nad długotrwałym bezrobociem (Woras-Kardach, Kostrzewski 2014; Griep i in. 2016; Thern i in. 2017; Mousteri i in. 2018; Peláez-Fernández i in. 2019). Wysoki wynik uzyskany w zakresie samosku- 
teczności wynikać może z charakteru badanej grupy, do której zostali zakwalifikowani bezrobotni biorący udział w projekcie mającym pomóc im w powrocie na rynek pracy po przeszło 12-miesięcznym okresie bez zatrudnienia. Mogło to czasowo podnieść wynik i wskazywać na rosnące poczucie zadowolenia z własnych zdolności w realizację celów. Niskie wyniki w zakresie optymizmu wskazują na raczej pesymistyczne nastawienie wobec powrotu na rynek pracy, związany z wpływem długotrwałego bezrobocia, są zatem zbieżne z dotychczasowymi doniesieniami badawczymi (Lai, Wong 1998). Tak duży odsetek osób z niskimi zdolnościami w obrębie inteligencji emocjonalnej jest interesujący, szczególnie w grupie młodych osób, i być może jest niezbadanym dotychczas determinantem długotrwałego bezrobocia.

Stwierdzony w analizowanych badaniach złożony charakter powiązań między poczuciem satysfakcji z życia a zasobami podmiotowymi wskazuje na potrzebę pogłębienia badań. Osoby bezrobotne charakteryzują się wysokim poziomem samoskuteczności przy relatywnie niskiej satysfakcji z życia, inteligencji emocjonalnej, cechując się tendencją do pesymizmu. Wykazano istotne dodatnie powiązania satysfakcji z życia z optymizmem dyspozycyjnym i poczuciem własnej skuteczności oraz ujemne $z$ inteligencją emocjonalną. Wyniki wskazujące na zwiększone zaangażowanie $\mathrm{w}$ realizację celów, pozytywne nastawienie do życia i przyszłości oraz niskie zdolności do wnikania w stany emocjonalne wiążą się z wyższą oceną własnego życia i nie poddają się jednoznacznym interpretacjom. Dane można też uznawać za wskaźniki funkcjonowania osób długotrwale bezrobotnych. Podstawową formą aktywności dorosłego człowieka jest planowe działanie w celu samorealizacji i zaspokajania materialnych i niematerialnych potrzeb, dlatego deprywacja tak rozumianej pracy sprzyja występowaniu negatywnych zjawisk. Stąd konieczne są wzmożone działania nad psychologicznym i psychoterapeutycznym przygotowaniem osób bezrobotnych do powrotu na rynek pracy.

Prezentowane badania nie pretendują do uogólnien, ale stanowią przyczynek do działań w tym kierunku. Mimo ograniczeń związanych z doborem próby i narzędzi mogą stanowić punkt wyjścia do szerszych badań, przyczyniając się do rozwoju zarówno teorii, jak i praktyki związanej z podejmowanym w artykule problemem. Rozpoznanie zasobów psychicznych i ich odpowiednia stymulacja mogą być użyteczne w budowaniu programów wspierających aktywność osób bezrobotnych na rynku pracy, niezależnie od tego, czy ich poziom jest przyczyną bezrobocia czy jego skutkiem. Wsparcie psychologiczne na etapie poszukiwania pracy, budowanie dobrostanu, kształtowanie poczucia sprawczości stanowią podstawę do efektyw- 
nego poszukiwania zatrudnienia. Działania aktywizacyjne osób długotrwale bezrobotnych powinny bazować na budowaniu motywacji do podjęcia pracy zarobkowej poprzez minimalizowanie zjawiska wyuczonej bezradności i podnoszenie wiary w skuteczność swoich działań. Odnajdywanie indywidualnych zasobów osób bezrobotnych, doskonalenie umiejętności istotnych na rynku pracy oraz zapewnienie wsparcia mogą uzupełnić istniejące rozwiązania systemowe do walki z bezrobociem lub stanowić podstawę do opracowania nowego modelu pracy z osobami długotrwale bezrobotnymi $\mathrm{w}$ ramach doradztwa osobistego. Upowszechnienie go „niesie za sobą skuteczną pomoc osobom, które nie są w stanie poradzić sobie same w skomplikowanej rzeczywistości rynkowej oraz życiowej, co jest niewątpliwie powodem, dla którego warto go upowszechnić" (Kasicz-Stępień 2014, s. 86).

Udoskonalenie programów pomagających osobom bezrobotnym w rozwiązywaniu problemów życiowych z wykorzystaniem dostępnych im zasobów, ich diagnostyka oraz indywidualne i grupowe szkolenia w celu podniesienia poziomu inteligencji emocjonalnej i pozytywnego nastawienia do wyzwań powinny być aktualnym celem dla instytucji walczących ze zjawiskiem bezrobocia.

\section{Bibliografia}

Andrés A. R. (2005), Income inequality, unemployment, and suicide: a panel data analysis of 15 European countries, „Applied Economics”, nr 37, s. 439-451.

Berriors P., Extremera N., Nieto-Flores M. P. (2016), Exploring the socioemotional factors associated with subjective well-being in the unemployed, „PeerJ”, nr 4, s. $1-14$.

Blakely T. A., Collings S. C. D., Atkinson J. (2003), Unemployment and suicide. Evidence for a causal association?, „Journal of Epidemiology \& Community Health", nr 57, s. 594-600.

Brand J. E. (2015), The Far-Reaching Impact of Job Loss and Unemployment, „Annual Review of Sociology", nr 41, s. 359-375.

Brown D. J., Cober R. T., Kane K., Levy P. E., Shalhoop J. (2006), Proactive personality and the successful job search: a field investigation with college graduates, „Journal of Applied Psychology", nr 91, s. 717-726.

Butterworth P., Leach L. S., Pirkis J., Kelaher M. (2012), Poor mental health influences risk and duration of unemployment: a prospective study, „Social Psychiatry and Psychiatric Epidemiology", vol. 47, nr 6, s. 1013-1021.

Caspi A., Wright B. R. E., Moffitt T. E., Silva P. A. (1998), Early failure in the labor market: Childhood and adolescent predictors of unemployment in the transition to adulthood, „American Sociological Review”, nr 63, s. 424-451. 
Clark A., Georgellis Y., Sanfey P. (2001), Scarring: the psychological impact of past unemployment, „Economica”, nr 68(270), s. 221-241.

Classen T. J., Dunn R. A. (2012), The effect of job loss and unemployment duration on suicide risk in the United States: a new look using mass-layoffs and unemployment insurance claims, „Health Econ”, nr 21(3), s. 338-350.

Creed P. A., Bloxsome T. D., Johnston K. (2001), Self-Esteem and Self-Efficacy Outcomes for Unemployed Individuals Attending Occupational Skills Training Programs, „Community Work \& Family”, nr 4(3), s. 285-303.

Derbis R. (2000), Doświadczanie codzienności, Wydawnictwo WSP, Częstochowa.

Derksen J., Kramer I., Katzko M. (2002), Does a self-report measure for emotional intelligence assess something different than general intelligence? „Personality and Individual Differences", nr 32, s. 37-48.

Druskat V. U., Wolff S. B. (2001), Building the Emotional Intelligence of groups, „Harvard Business Review", nr 79, s. 80-87.

Duda M. (2019), Stracone pokolenie - młodość ryzykiem socjalnym, „Edukacja - Technika - Informatyka", nr 2(28), s. 116-121.

Fugate M., Kinicki A. J., Ashforth B. E. (2004), Employability: a psycho-social construct, its dimensions, and applications, „Journal of Vocational Behavior”, nr 65, s. 14-38.

Griep Y., Kinnunen U., Nätti J., De Cuyper N., Mauno S., Mäkikangas A., De Witte H. (2016), The effects of unemployment and perceived job insecurity: a comparison of their association with psychological and somatic complaints, self-rated health and life satisfaction, „International Archives Occupational Environmental Health", nr 89(1), s. 147-162.

Han K. (2005), Self efficacy, health promoting behaviors, and symptoms of stress among university students, „Taehan Kanho Hakhoe Chi”, t. 35, nr 3, s. 585-592.

Hobfoll S. E. (2006), Stres, kultura i społeczność. Psychologia i filozofia stresu, Gdańskie Wydawnictwo Psychologiczne, Gdańsk.

Hodzic S., Ripoll P., Bernal C., Zenasni F. (2015), The Effects of Emotional Competences Training among Unemployed Adults: A Longitudinal Study, „Applied Psychology: Health and Well-Being", vol. 7, nr 3, s. 275-292.

Ishmuhametov I., Palma A. (2017), Unemployment as a Factor Influencing Mental Well-Being, „Procedia Engineering”, nr 178, s. 359-367.

Janicki-Deverts D., Cohen S., Matthews K. A., Cullen M. R. (2008), History of unemployment predicts future elevations in $\mathrm{C}$-reactive protein among male participants in the coronary artery risk development in young adults (CARDIA) study, „Annals of Behavioral Medicine”, nr 36, s. 176-185.

Jordan P. J., Ashkanasy N. M., Hartel C. E. J., Hooper G. S. (2002), Workgroup emotional intelligence: Scale development and relationship to team process effectiveness and goal Focus, „Human Resource Management Review”, nr 12, s. 195$-214$.

Juczyński Z. (2001), Narzędzia pomiaru w promocji i psychologii zdrowia, Pracownia Testów Psychologicznych, Warszawa. 
Kalbarczyk A. (2011), Metody efektywnej pomocy psychologicznej w pracy doradcy zawodowego z osobq bezrobotna, Ministerstwo Pracy i Polityki Społecznej, Warszawa.

Kalil A. (2009), Joblessness, family relations and children's development, „Family Matters", nr 83, s. 15-22.

Kasicz-Stępień G. (2014), Doradztwo osobiste. Podręcznik wspótpracy powiatowych urzędów pracy i ośrodków pomocy społecznej na rzecz osób długotrwale bezrobotnych, Wydawnictwo Instytut Śląski, Opole.

Kirenko J., Duda M. (2018), Bezrobocie - jakość życia - uwarunkowania, Wydawnictwo UMCS, Lublin.

Kokko K., Pulkinnen L., Puustinen M. (2000), Selection into long-term unemployment and its psychological consequences, „International Journal of Behavioral Development”, vol. 24, nr 3, s. 310-320.

Kposowa A. J. (2001), Unemployment and suicide: a cohort analysis of social factors predicting suicide in the US National Longitudinal Mortality Study, „Psychological Medicine", nr 31, s. 127-138.

Kulik T. B., Pacian A., Pacian J., Janiszewska-Grzyb M. (2008), Bezrobocie a zdrowie: wybrane problemy, „Acta Scientifica Academiae Ostroviensis”, nr 31, s. 5-15.

Lai J. C. L., Wong W. S. (1998), Optimism and coping with unemployment among Hong Kong Chinese women, „Journal of Research in Personality”, nr 32, s. 454-479.

Li W. D., Li S., Fay D. (2019), Reciprocal Relationships Between Dispositional Optimism and Work Experiences: A Five-Wave Longitudinal Investigation, „Journal of Applied Psychology", nr 104(12), s. 1471-1486.

Liberska H. (2016), Wybrane podmiotowe i kontekstualne uwarunkowania satysfakcji z życia w okresie późnej dorosłości. Badania porównawcze, „Rocznik Andragogiczny", nr 23, s. 217-231.

Liu S., Wang M., Liao H., Shi J. (2014), Self-regulation during job search: The opposing affects of employment self-efficacy and job search behavior self-efficacy, „Journal of Applied Psychology", nr 99, s. 1159-1172.

Lubińska-Bogacka M. (2011), Społeczno-edukacyjne problemy rodzin bezrobotnych, Wydawnictwo Naukowe Uniwersytetu Pedagogicznego, Kraków.

Matczak A., Jaworowska A. (2008), INTE - Kwestionariusz Inteligencji Emocjonalnej INTE, Pracownia Testów Psychologicznych, Warszawa.

Matsumoto D., LeRoux J. A., Bernhard R., Gray H. (2004), Unraveling the psychological correlates of intercultural adjustment potential, „International Journal of Intercultural Relations", nr 28, s. 281-309.

Mayer J. D., Salovey P. (1999), Czym jest inteligencja emocjonalna, [w:] P. Salovey, D. J. Sluyter (red.), Rozwój emocjonalny a inteligencja emocjonalna, Wydawnictwo Rebis, Poznań, s. 23-69.

McKee-Ryan F. M., Kinnicki A. J., Song Z., Wanberg C. R. (2005), Psychological and physical well-being during unemployment: a meta-analytic study, „Journal of Aplied Psychology", vol. 90, nr 1, s. 53-76. 
Moore T. H. M., Kapur N., Hawton K., Richards A., Metcalfe C., Gunnell D. (2017), Interventions to reduce the impact of unemployment and economic hardship on mental health in the general population: A systematic review, „Psychological Medicine", nr 47, s. 1062-1084.

Mossakowski I. N. (2009), The Influence of past unemployment duration on symptoms of depression among young women and men in the United States, „American Journal of Public Health", nr 99(10), s. 1826-1832.

Mousteri V., Daly M., Delaney L. (2018), The scarring effect of unemployment on psychological well-being across Europe, „Social Science Research”, nr 72, s. 146-169 .

Munyon T. P., Hochwarter W. A., Perrewé P. L., Ferris G. R. (2010), Optimism and the nonlinear citizenship behavior - Job satisfaction relationship in three studies, „Journal of Management”, nr 36(6), s. 1505-1528.

Myszka-Strychalska L. (2018), Przygotowanie do startu w dorosłość - młodzież w okresie tranzycji z edukacji na rynek pracy, „Rocznik Andragogiczny”, vol. 25, s. 229-247.

Park S. G., Min K. B., Chang S. J., Kim H. C., Min J. Y. (2009), Job stress and depressive symptoms among Korean employees: the effects of culture on work, „International Archives Occupational Environmental Health", nr 82, s. 397-405.

Paul K., Moser K. (2009), Unemployment impairs mental health: Meta analyses, „Journal of Vocational Behavior”, nr 74, s. 264-282.

Peláez-Fernández M. A., Rey L., Extremera N. (2019), Psychological distress among the unemployed: Do core self-evaluations and emotional intelligence help to minimize the psychological costs of unemployment?, „Journal of Affective Disorders", nr 256, s. 627-632.

Pinquart M., Juang L. P., Silbereisen R. K. (2003), Self-efficacy and successful schoolto-work transition: a longitudinal study, „Journal of Vocational Behavior”, nr 63, s. 329-346.

Ślebarska K., Chudzicka-Czupała A. (2013), Emotional costs and self-efficacy as predictors of coping among the reemployed and professional interns, „Sociology Study", nr 3(5), s. 354-362.

Ślebarska K., Moser K., Gunnesch-Luca G. (2009), Unemployment, social suport, individual resources and job search behavior, „Journal of Employment Couseling”, nr 46, s. 159-170.

Śmieja M., Orzechowski J. (2008), Inteligencja emocjonalna: fakty, mity, kontrowersje, Wydawnictwo PWN, Warszawa.

Tahmassian K., Moghadam J. N. (2011), Relationship between self-efficacy and symptoms of anxiety, depression, worry and social avoidance in a normal sample of students, „Iranian Journal of Psychiatry and Behavioral Sciences”, nr 5, s. 91-98.

Thern E., de Munter J., Hemmingsson T., Rasmussen F. (2017), Long-term effects of youth unemployment on mental health: does an economic crisis make a difference? „Journal of Epidemiology and Community Health”, nr 71(4), s. 344-349. 
Van Hoye G., Lootens H. (2013), Coping with unemployment: Personality, role demands, and time structure, „Journal of Vocational Behavior”, vol. 82, nr 2, s. $85-95$.

Wanberg C. R. (2010), The individual experience of unemployment, „Annual Review of Psychology", nr 63(63), s. 369-396.

Wanberg C. R., Hough L. M., Song Z. (2002), Predictive validity of a multidisciplinary model of reemployment success, „Journal of Applied Psychology”, nr 87, s. 1100-1120 .

Wang Y., Yao L., Liu L., Yang X., Wu H., Wang J., Wang L. (2014), The mediating role of self-efficacy in the relationship between Big five personality and depressive symptoms among Chinese unemployed population: A cross-sectional study, „BMC Psychiatry", nr 14(61), s. 1-8.

Wojciechowska Z. (2018), Źródła i rodzaje zmian zawodowych w biografiach młodych dorosłych, „Rocznik Adragogiczny”, vol. 25, s. 249-266.

Wong C. S., Law K. S. (2002), The effects of leader and follower emotional intelligence on performance and attitude: An exploratory study, „The Leadership Quarterly”, vol. 13, nr 3, s. 243-274.

Woras-Kardach H., Kostrzewski S. (2014), Quality of Life and Health State of Long - Term Unemployed in Older Production Age, „Applied Research in Quality of Life" vol. 9, nr 2, s. 335-353.

Wrona-Polańska H. (2012), Psychologia zdrowia w służbie człowieka - rola zasobów podmiotowych, [w:] H. Wrona-Polańska (red.), Psychologia zdrowia w służbie człowieka, Wydawnictwo Naukowe Uniwersytetu Pedagogicznego, Kraków 2012.

Zeidner M., Matthews G., Roberts R. D. (2004), Emotional intelligence in the workplace: A critical review, „Applied Psychology”, nr 53 (3), s. 371-399.

\section{Netografia}

Lee K. W. (2008), Psychological consequences of unemployment among Hong Kong university graduates: The impact of optimism, coping and motivation, http://lbms03. cityu.edu.hk/oaps/ss2008-4708-lkw306.pdf (dostęp: 20.11 2019). 